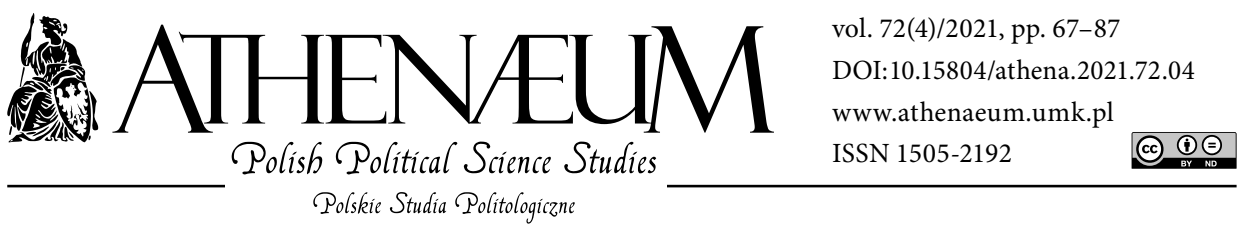

\title{
POLITICAL AND ECONOMIC DETERMINANTS OF THE ATTITUDES OF THE YOUNG GENERATION IN THE RUSSIAN FEDERATION IN 2020-2021
}

\author{
UWARUNKOWANIA POLITYCZNO-EKONOMICZNE POSTAWY \\ MŁODEGO POKOLENIA W FEDERACJI ROSYJSKIEJ W LATACH \\ 2020-2021
}

Mateusz Kamionka*๑, Paweł Bielicki**๑ఠ

\begin{abstract}
The aim of our considerations is to present the most important determinants and implications characterizing the views of the young generation of Russians on the political and economic events taking place in the Russian Federation in 2020-2021. The subject of our interest will be the analysis of the causes of growing disapproval of young people towards the president of the country, Vladimir Putin, in this period.

At the beginning of this study, we will examine the political situation in Russia following Putin's next re-election in March 2018 and the deterioration in the economic situation of the country's young citizens, multiplied by the outbreak and development of the coronavirus pandemic. An important problem that we faced is the attitude towards the return to the country in January 2021 of the oppositionist Alexei Navalny and his immediate detention by repressive state
\end{abstract}

\begin{abstract}
ABSTRAKT
Celem naszych rozważań jest przedstawienie najważniejszych uwarunkowań i implikacji charakteryzujących poglądy młodego pokolenia Rosjan na wydarzenia polityczno-ekonomiczne, mające miejsce w Federacji Rosyjskiej w latach 2020-2021. Przedmiotem naszego zainteresowania będzie analiza przyczyn zjawiska rosnącej $\mathrm{w}$ tym przedziale czasowym dezaprobaty młodych wobec prezydenta kraju Władimira Putina.

$\mathrm{Na}$ wstępie niniejszego studium prześledzimy sytuację polityczną Rosji po kolejnej reelekcji Putina w marcu 2018 r. i pogorszenie się sytuacji gospodarczej młodych obywateli tego kraju, zwielokrotnione na skutek wybuchu i rozwoju pandemii koronawirusa. Ważnym problemem, z którym się mierzymy, jest także ustosunkowanie się do powrotu do kraju w styczniu 2021 r. opozycjonisty Aleksieja Nawalnego i jego
\end{abstract}

* Pedagogical University of Kraków, Institute of Political Science and Administration.

** Asia and Pacific Society in Toruń. 
authorities, resulting in social protests, in which young Russians widely participated. It will also be important to analyze the role of social media in shaping the views of Russian youth. In addition, we will discuss the issue of economic problems of the Russian state that are increasing in strength, affecting the condition of the part of Russian society that is entering adulthood.

In conclusion, we would like to answer the questions to what extent the disappointment of young Russians towards the person and government of Putin will contribute to the decline in support for him, and whether the Kremlin has real instruments to reverse the trend that is negative for the rulers.

Keywords: economy; youth; Navalny; politics; Putin; determinants zatrzymania przez represyjne organa państwa, skutkującego społecznymi protestami, których uczestnikami są także młodzi Rosjanie. Istotnym będzie także przeanalizowanie roli mediów społecznościowych w kształtowaniu się poglądów rosyjskiej młodzieży. Dodatkowo poruszymy kwestię przybierających na sile problemów ekonomicznych państwa rosyjskiego, odbijających się na kondycji wchodzącej w dorosłość części rosyjskiego społeczeństwa.

W podsumowaniu chcielibyśmy udzielić odpowiedzi na pytania, na ile rozczarowanie młodych Rosjan osobą i rządami Putina przyczyni się do spadku poparcia dla niego oraz czy Kreml ma realne instrumenty pozwalające na odwrócenie negatywnego dla rządzących trendu.

Słowa kluczowe: ekonomia; młodzież; Nawalny; polityka; Putin; uwarunkowania

\section{INTRODUCTION}

Recent events related to the SARS-CoV-2 coronavirus pandemic have become an opportunity to present the course of social processes differentiated from its background in almost every country in the world, including the largest ones characterized by high propensity to socio-economic changes forced by the development of the epidemic situation within their country limits. One of such countries is the Russian Federation, ruled by President Vladimir Putin. The main purpose of this article will be to present the most important political and economic determinants of the protests of young citizens of the Russian Federation in 2020 and 2021 resulting from the emergence and course of the epidemic. The subject of our interest will be an attempt to analyze the reasons why young Russians became more involved in protests against the authoritarian power of their president during this period. It will also be important to trace the significance of COVID-19 in the process of the decline in the trust of young citizens of the Russian state in the authorities in the Kremlin. At the same time, we must not forget the content of the return to Russia by the oppositionist Alexei Navalny, after the immediate detention of whom, many residents, especially in Moscow and Saint Petersburg, decided to protest against such a move by the rulers. The economic problems of the young Russian generation, resulting from the insufficient attention of the 
authorities to the social situation of this social class, will also be worth noting. The basic research hypothesis adopted by the authors is the supposition that the above protests will contribute to the deepening of negative opinions about the person and actions of Putin and the Russian government among this age group, which may cause significant problems for the regime in the long run. It seems to be advisable to ask the following research questions: What factors led to the increase in political activity of Russian youth in 2020? What was their reaction to further restriction of democratic freedoms in Russia? What role did Alexei Navalny play in the development of the protests? How did the authorities react to the protests resulting from the actions of state administration bodies? What role did social media play in shaping opposition attitudes? How did young Russians react to the film titled "Putin's Palace" published before the arrival and arrest of Navalny, detailing the abuse and corruption of the main dweller of the Kremlin? How does the deteriorating economic situation of the country affect the political attitudes of the young generation? Should such opposition attitudes towards the long-term ruler President Putin be expected to radicalise in the future?

\section{POLITICAL ASPECTS OF THE ACTIVITY OF YOUNG RUSSIANS}

IN 2020-2021

Considering this issue, we must point out that the growing activity of young Russians in the period of interest to us is due to the intensification of political repression in the Kremlin, the progressing erosion of the rule of Putin and his acolytes since 2018, and the deteriorating economic situation of the citizens of the Russian Federation. The Russian president, elected for the next - fourth term, since his last re-election began to devote less and less attention to internal affairs, and he focused on the implementation of the Federation's global interests. This was reflected in the growing presence of Russia in Syria and Libya, where, from April 2019, Moscow began to play a decisive role by sending anti-tank missiles and anti-aircraft batteries to the army of General Khalifa Haftar's support, while conducting an operation discrediting the pro-Western government in Tripoli (Gresh, Jones, \& Loughran, 2020, p. 68). The Kremlin's field of activity was also the United States, and in Europe it was mostly Belarus, whose president Alexander Lukashenko since the appointment of Mikhail Babich to Russia in August 2018, has been subjected to significant pressure to strengthen political and economic ties with Russia (Kacewicz, 2019). In this situation, the social and 
economic problems of Russia itself were of less interest to the authorities, including the then prime minister of the country, Dmitry Medvedev, who was unable to boost his cabinet's economic policy. His ratings were also lowered due to the information disclosed at the time by Navalny about the wealth of the then head of government and the fact that he owns a residence worth several billion rubles (see: "On nie jest dla was Dimkq"..., 2019). As a result of growing social anxiety and an attempt to present himself as a "good tsar" who cares about the standard of living of an ordinary Russian, in January 2020, Putin decided to dismiss his predecessor and appoint in his place Mikhail Mishustin, perceived as an efficient technocrat, who could initiate a social program for the poorest Russians (Bielicki, 2020, p. 109). In reality, however, the new prime minister turned out to be an obedient executor of Putin's orders, who continued to fear radical economic reforms that could lead to a possible depreciation of his power.

All the problems in Russia were then highlighted by the COVID-19 pandemic, which started in March 2020. As a result of delayed and inconsistent actions of the government, and Putin's ceding responsibility for fighting the virus to lower levels of government, young Russians began to clearly see the shortcomings of the president's model of state management. The impact of the epidemic on his support among young people is proved by the fact that while in December 2019, 36\% supported the president's actions, in November 2020 this percentage decreased to $20 \%$ (Reyting Putina sredi molodezhi..., 2020). The data presented above are confirmed by Denis Volkov, the deputy director of the Levada Center who is relatively independent of the Kremlin's authorities. In his opinion, the coronavirus pandemic has clearly exposed the critical attitude to the government among the younger generation. Moreover, he argues that the intensification of the loss of trust in Putin is more evident in large urban centers, where access to media sources varies. This process is slower in regions where people only watch TV (see: Młodzi Rosjanie problemem dla Putina..., 2021). It is significant that during the referendum for constitutional changes and the extension of the president's term of office in July 2020, when asked what is considered the most important amendment to the constitution, more than half of the young Russians surveyed mentioned the need to maintain social guarantees, including pension indexation and the minimum wage. For comparison, only $13 \%$ of the respondents declared that changes in the political system are the most important for them. At the same time, as many as $40 \%$ of those polled would definitely approve of Putin's departure in 2024 (Sasse \& Krawatzek, 2020). 
In view of the above, it should be assumed that the COVID-19 pandemic and the progressive tightening of the course towards the opposition made the young Russian society aware that the government, showing ever stronger symptoms of gerontocracy, is incompetent to govern and does not understand the real problems of young people. The problem is important for the Kremlin because the young generation who do not remember the declining times of the USSR, including the extremely fateful rule of Boris Yeltsin, only remember the Putin era and see that the standard of living has not improved much over the past years. They do not remember that during the first two presidential terms in 2000-2008, there was a significant increase in Russian incomes compared to the 1990s, when the monthly salary amounted to just a few dozen dollars. Until the annexation of Crimea and the introduction of sanctions by the West, a Russian resident earned an average of $\$ 450$ a month (see: A Hollow Superpower, 2016). However, Putin has gradually become an anachronistic leader for young people, the proverbial "old man in a bunker" detached from real problems, as Tatiana Stanovaya points out (Kolesnychenko, 2021).

The case of Alexei Navalny became a bit of bitterness, which in a way became a catalyst for the rebellion of young people. For young Russians, for whom freedom is a fundamental value (Martynov, 2021), the fate of the oppositionist and his persecution by the Kremlin became an opportunity to express dissatisfaction with the failure to respect democratic values. Although Navalny became involved in opposition activities in 2006 and he began to organize political meetings in Moscow (Bennetts, 2014, p. 122), continued in the following years, mainly in Moscow and St. Petersburg, among many people, outside large metropolises, he was a relatively unknown person presented by the Kremlin as a person who serves the interests of foreign entities. Along with the development of social media and thanks to the relatively autonomous Internet network, it began to gain more and more popularity. The attempt to poison him, made in August 2020 in Omsk, probably on the orders of the Russian authorities, did not initially gain wider public reception and did not cause significant protests among young people. However, young Russians confirmed in research that in their opinion the Kremlin was involved in the attempted murder of the oppositionist. The poll showed that as much as $34 \%$ of young respondents believed that the Russian authorities poisoned Navalny in order to get rid of their political rival (Kolesnikov, 2021). While the subdued reaction in August 2020, immediately after the attempted assault, can be explained by the ambiguity of the backstage of the operation, as well as by the events in Belarus after the rigged presidential 
elections by the Lukashenko regime or the detention of Sergei Furgal (the mayor of Khabarovsk, Putin's opponent, suspected of ordering the murders of two businessmen) by the FSB, however, after Navalny's conversation on the phone with the officers responsible for his attempted poisoning, a conviction arose that Russia is a country where the leader and his associates are able to make decisions about the liquidation of a known political adversary without hesitation and scruples, using a strong poison. Drawing inspiration from the events in Khabarovsk and the protests against Lukashenko (Pozychanyuk, Khokhlov, \& Mironenko, 2021), the demonstrators realized that after many years there was a politician who was able to take a real challenge against the authorities in Moscow. There is no doubt that Navalny's arrival in Moscow in January 2021 and his detention at the airport showed young people that the authorities would do everything to sink their opponent and thus curtail all democratic freedoms. This explains the fact that about $40 \%$ of Russian youth decided to take part in protests against the government (Kolesnikov, 2021). After all, the core of the protests were still people previously involved in the fight against the regime. According to research carried out by the Carnegie Moscow Center and Levada Center, young people want significant changes in the political and economic system of Russia and see that the Kremlin only wants to keep the privileges for the ruling elite and does not want to increase the standard of living of an ordinary Russian (Kolesnikov, 2021).

The government's reactions to the growing protest activity of young Russians revealed some concern about the development of the situation, but the Kremlin's political strategy was mainly seen as attempts to slander Navalny in the eyes of this social group. The pro-government media emphasized that both he and his supporters manipulated public opinion. The comment of the Russian Ministry of Internal Affairs is significant. He suggested that the opposition's associates received orders from abroad to influence the views of young and underage Russians as much as possible and to encourage them to organize mass riots (Bryc, 2021). This position was also shared by Putin's spokesman, Dmitry Peskov, saying that it is unacceptable to provoke young people to participate in protests (Kreml' nazval..., 2021). Russian propaganda also tried to show that they are increasingly being steered not only by the opposition, but also by other adult citizens. Such a view was expressed by one of the columnists, Irada Zeynalova, who believed that young people are visually flexible and it is easy to convince them to even the most absurd statements, and adults should not use the natural leftist and rebellion reflex to achieve their own goals (Starchenko, 2021). It seems that the Kremlin is trying to portray young people as politically unoriented and 
"immature" who are often unwittingly engaged in foreign services aimed at causing anarchy in the country by making such statements. A classic example used by the state-controlled mass media was when describing the events in the United States on January 6, 2021, when the demonstrators, most of whom were supporters of the stepping down president of the country, Donald Trump, invaded the Capitol. In this context, Putin's statement is significant. During the meeting with students, he emphasized that demonstrations against the government are permissible, but within the "legal framework", and not in the way it was in the United States. Putin emphasized that Americans also took to the streets under political slogans, but "beyond the legal framework". Not hiding his satisfaction with the events in the USA, the Russian president asked why everything should be allowed in Russia (see: „Tak postępują terroryści”..., 2021). By arguing that the protesters wanted to destabilize the country, those favouring the Russian president resorted to offensive language. In this context, the words of Dmitry Kiselyov, the main Russian propagandist, are significant. On January 24, he said that most of the demonstrators were "underaged" and controlled by a "Berlin patient". He sassily accused the opponents of the system and their families of involving children in politics like "political pedophiles". It should be noted that the journalist's argumentation is inconsistent with the facts, because according to sociologists studying the number of participants in the protests in Moscow, in the group under 18 , out of 300 people, only $4 \%$ have not reached the age of majority (Starchenko, 2021). Still other data are provided by Alexandra Arkhipova, a social anthropologist. According to her, $1.7 \%$ of minors participated in the protests in Moscow, $24 \%$ - from 18 to 24 years old, $42 \%$ - from 25 to 35 years old, $15 \%$ from 36 to 46 years old, $10.9 \%$ - from 47 to 57 years, and $6.1 \%$ - over 58 years of age. Among the protesters, $13.6 \%$ attended the protest for the first time (see: Novaya aktsiya..., 2021).

Despite its boisterous rhetoric, the Kremlin cannot ignore the worsening mood among underage voters, because over the years, they will be those making decisions in the elections. According to the Russian sociologist Alexei Frisov, their opposition cannot be suppressed by traditional means of coercion, but other methods of influence should be sought. The analyst claims that the reluctance of minors is a very unfavourable scenario for the Kremlin authorities, which is why the government had to clearly intimidate them against participating in demonstrations (Kolesnychenko, 2021). It was not a coincidence that in many cities of the Russian Federation, many students and parents received letters warning about the consequences of participating in protest actions. Educational 
authorities and school management also resorted to a trick, introducing stationary organization of classes and other school events on January 23, disregarding the distance learning in force at that time, imposed by epidemic requirements (see: Vlasti Bashkirii prizvali roditeley..., 2021). A similar method was used for students, among others, in the Astrakhan University, who were additionally threatened with expulsion from the university if they joined the demonstration (Kolesnychenko, 2021). Representatives of other Russian universities also declared that their students could be entered on the "black list of state institutions" (Zhukov, 2021), which for them may mean that in the future they may have a significant problem with finding a job in institutions related to the Kremlin or in local government bodies. Such activities among well-educated Russians, relatively well-versed in the political system of the USSR, raise analogies with the persecution that took place during the Soviet era. The statements of, among others, 25-year-old Anastasiya Kuzmina, who works in an advertising agency, emphasize that the intensification of the current police terror is associated with the peak period of Stalinist repression in 1937. Nikolay Babikov, 31, a computer systems analyst from Moscow, pronounces a similar opinion, claiming that the elimination of civil liberties in Russia is reminiscent of the times of the Soviet Union (Troianovski et al., 2021). The same testimony was given by Svetlana Wasser, detained on the last day of January, and her roommate said that the fate of the opposition activists resembled Stalinist terror (Rescheto, 2021). According to Paweł Kowal, young people go to the streets because they no longer want to live in a country dominated by oligarchs and power structures (see: Kowal: Nawalny musi dostosować narracje..., 2021).

Another reason why young people are protesting in the streets is the still growing corruption of Russian regional and central elites, including Putin himself. A key role in this aspect was played by the film entitled "Putin's Palace", showing the highly probable financial deprivation of the Russian leader, the fruit of which can be a huge and unprecedentedly splendid estate in Gelendzhik on the Black Sea. The extent of the broadcast is demonstrated by the fact that $26 \%$ of the adult Russian population have watched it, and another $10 \%$ know its content, although they have not seen the film itself. Moreover, $32 \%$ have heard of it but do not know the details, and the next $31 \%$ of respondents have not heard anything about the documentary (see: Fil'm "Dvorets dlya Putina", 2021), It should be noted that younger Russians, who have regular access to social networks, watched the film in greater numbers than other social groups - in the age group between 18 and 24, as many as 37\% (Starchenko, 2021). 33\% believe that the information 
contained in the film is untrue, $38 \%$ that the statements of the authors are close to the truth, but it is difficult to assess the credibility of the allegations with $100 \%$ sureness, and $17 \%$ of the respondents are convinced that the assumptions it presents are correct. It is important that as many as 59\% of respondents aged 18-24 believe that the information is close to the truth, and $23 \%$ believe that the allegations are credible. Only 29\% believe that Putin has never abused his power, and another $24 \%$ believe that even if such accusations are true, under his rule the people live better than before. Additional inquiries to the respondents specify that $17 \%$ of respondents believe that the Russian president is definitely guilty of abuses, and a further $25 \%$ that he is equally guilty as other high-level officials. It is significant that as many as $25 \%$ of respondents aged 18 to 24 are definitely convinced about the truth of the accusations made by Navalny against Putin. The most sceptical of the information contained in the film are people aged 55 and older and viewers watching state-controlled and other related television channels - 13\% (Fil'm "Dvorets dlya Putina", 2021). Regardless of the statistics presented above, it should be emphasized that the film in question caused a great deal of indignation among young Russians, because the cost of building a palace or the prices of equipment and accessories, including the toilet brush, significantly exceeded the value of the average monthly salary in most regions of the Russian Federation (Domańska \& Rogoża, 2021). The young people felt personally touched by the fact that they themselves, having no prospects for the future and being unable to become independent, watched through unofficial channels the president wallowing in luxury, presenting himself in the media as an honest and just leader. The expression of bitterness can be seen in the statement of a 24-year-old student who stated that, for example, doctors receive a bonus for their work in the form of only 17,000 rubles (223 dollars - MK, PB). As she added, the video presented by Navalny filled her with bitterness and that is why she went to protest (see: Not Just Navalny..., 2021).

It should also be made clear that for many years young people have been much less tolerant of bribery than their parents or grandparents, as evidenced by the fact that high school students and students have been participating in protests against the abuse of power in this area for years, an example of which is the action condemning the corruption of top Kremlin officials organized by Navalny back in 2017 and supported by young people (Meyer-Olimpieva, 2019). The growing role of social media is particularly conducive to making the Russians aware of the degree of demoralisation of government officials. So undoubtedly, the growing criticism of the regime is influenced by the fact that 
since 2018, the number of YouTube and Instagram users has doubled (see: Młodzi Rosjanie problemem dla Putina..., 2021). According to the All-Russian Research Center GfK, by the beginning of the year mentioned, as many as 87 million, out of 146.8 million of Russians above the age of 16, used the Internet (Shurlakova \& Wojtkowiak, 2018, p. 172). Seeing a different world on the Internet than that presented by the Russian government, young people began to believe that Russia's political and economic reality is significantly opposed to that presented by Russian propaganda. The Kremlin seems to have recognized the problem as Rosmolodezh, the government agency responsible for implementing national youth policy, was transferred in 2018 to the direct supervision of high-level officials in the president's administration (Starchenko, 2021).

Such actions, however, can be considered as far insufficient, because it is Navalny via Youtube and his own social media that show that there is a source of information other than the official one. This message is addressed mainly to young people, who are the oppositionist's main recipients (Moroz, 2020, p. 256). He seems to have wanted to use young people from the outset to create a broader political plane, suggesting that it is crucial to mobilize them in the fight against the regime. He was right to emphasize that his Internet channel is watched by young people - both schoolchildren and students. Navalny openly pointed out that due to the fact that the youth are the future of the country, they should exert strong pressure on the government and become more politically involved (Moroz, 2020, p. 262). Recognizing such a threat, in 2018 the Russian authorities blocked Telegram for allegedly failing to comply with anti-terrorist regulations (Asmolov \& Kolozaridi, 2020, p. 287). According to Elena Omelchenko, head of the Youth Research Center at the Higher School of Economics in St. Petersburg, young Russians are in a critical situation in which we are dealing with an increasing need for self-fulfilment and with the growing role of the state in the sphere of ideology and education. The analyst stressed that young people living in large cities with access to the Internet do not differ much from their peers from the West (see: Młodzi Rosjanie problemem dla Putina..., 2021) and would like to enjoy similar civil liberties. Any attempts to block social media, suggested by the Russian prosecutor general, may end in a fiasco at this stage (Roth, 2021). A more important problem that the Kremlin has been unable to overcome since the collapse of the USSR is the poor economic situation of the young generation. 


\section{THE ECONOMIC SITUATION OF THE YOUNG GENERATION OF RUSSIANS AND ITS INFLUENCE ON THE POLITICAL MOOD}

Since the beginning of 2021, an increasing number of Russians believe that in the near future public activity will increase and protests for economic reasons will intensify. In the opinion of Levada Center, this view was declared by $43 \%$ of the respondents. Thus, this result came close to 1998 , when $48 \%$ of the respondents answered the same question in the affirmative. It should be remembered that the end of the $1990^{s}$ was the period of one of the greatest economic crises in the then Russia, when the country ceased to matter on the global economic arena for several years. At that time, foreign capital was withdrawn from there, which aggravated the stagnation of the economy and contributed to Putin's taking the office of Prime Minister and then of the President. Therefore, we cannot underestimate today's research results, the more so as they show the disapproval of Russian citizens towards the Kremlin's economic policy and see the increasing effects of both the economic and pandemic crisis in their homeland. It is worth noting here that, according to research, Western sanctions do not affect the situation of Russians for as many as $57 \%$ of those questioned. Only $3 \%$ of the respondents consider these restrictions a serious problem (see: Antirossiyskiye sanktsii, 2020). This suggests that the level of declarations of participation in the protests was only $17 \%$, which may indicate the tiredness and dissatisfaction of the Russian society with the country's economic situation (see: Yanvarskiye protesty, 2021). However, it should be noted that the low level of the number of people willing to manifest demonstrates that Russians do not believe there could be an alternative to Putin. The Russian youths are a particularly active group of protesters, showing the greatest "revolutionary" activity. It is therefore worth explaining why it plays a decisive role in the protests and how the state of the Russian economy has influenced this phenomenon.

One of the problems affecting the situation of young people in Russia is the level of unemployment among the youngest. According to Rosstat data, at the end of 2019, unemployment among people aged $20-24$ was $15.1 \%$ (i.e., 3.2 times more than in the whole of Russia) (Sukhovey, 2020). From year to year, the situation becomes more difficult if we take into account the increased retirement age, the dismissal of 2.8 million people during the pandemic and the 3 million people who have been transferred into part-time jobs (Trushin, 2020). Let us remember that in July 2021, the Russian labour market will be supplied by 1.25 to 1.5 million young people aged 15 to 24 who will graduate from schools. The 
results of research on the Russian 'Z Generation' show that $46 \%$ of respondents believe that schools and universities do not prepare them well to enter into the labour market. Moreover, in the opinion of young people, graduation does not mean a thorough comprehension of the curriculum. In the same study, as many as $47 \%$ of respondents answered that they agree that there are cases of corruption related to receiving a grade or passing an exam in higher education, and only $6 \%$ of respondents completely disagree with this opinion (Gudkov et al., 2020, pp. 84-85).

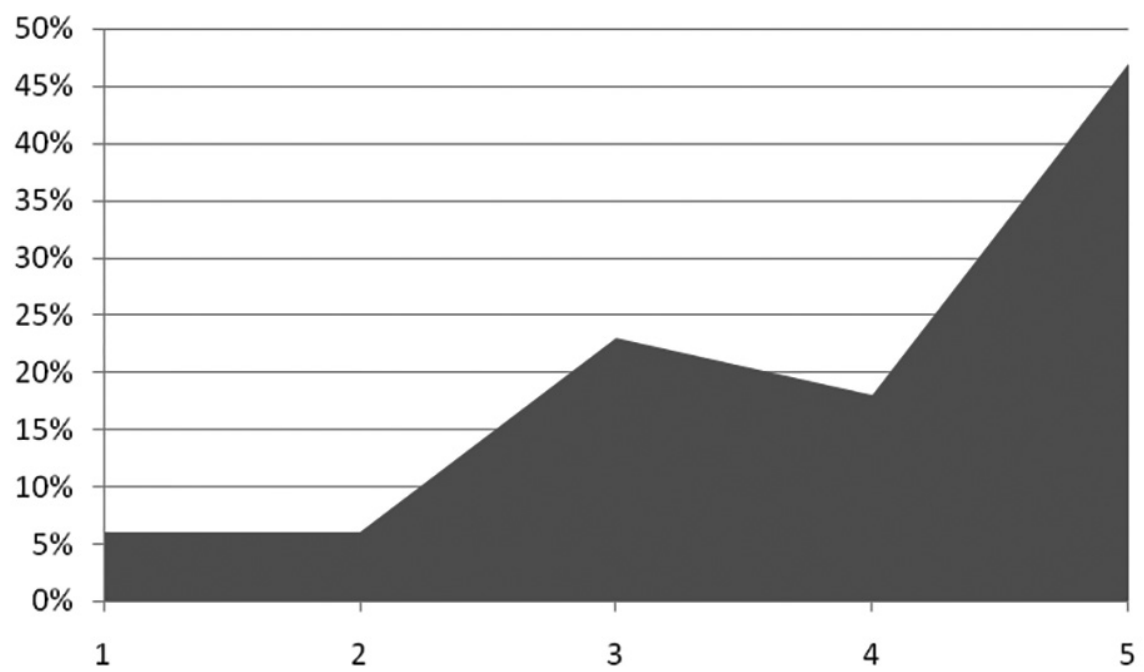

Chart. Do You Agree with the Opinion That There Are Cases of "Buying" Grades and Exams in Russian Universities? (1 - I do not agree at all, 5 - I fully agree)

Source: Gudkov et al. (2020).

The Russian Agency for Strategic Initiatives, together with experts from the Moscow School of Economics, forecast that the most urgent issue during the crisis is the fair distribution of resources between different generations, because mainly young people lost the opportunity to achieve their goals and dreams in 2020. Representatives of the above institutions express the view that this group may become the most vulnerable group facing possible economic shocks in Russia (Pandemiya koronavirusa mozhet..., 2020). However, it is difficult to demonstrate particular actions by the Russian government towards young people. In the opinion of prof. Alexander Zapesotsky, rector of the St. Petersburg Humanitarian 
University of Trade Unions, the Kremlin has not made an adequate attempt to solve the problem of youth unemployment. At the same time, he predicts that "unfortunately, a breakdown of society and an increase in social tension are very likely" (Zapesotsky, 2021). The correct hypothesis will be that Russian public opinion is not well informed about the real situation of young people. This is evidenced by "analyses" published in press articles. One of such cases is the text published on the website of the TASS news agency (see: Issledovaniye..., 2020) entitled "Research: Young People in Russia Turned Out to Be Best Prepared for the Economic Crisis". The article comments on a noteworthy report published in early 2020 by the insurance company "Rosgosstrakh Zhizn" and the bank "Otkrytie", concerning the life of the Russian youths. According to the authors of the article, the "ultra-conservative" habits of saving among young people result from the fact that they often live with their parents and do not spend money on municipal charges. On the other hand, if they live alone, unlike the older generation, they prefer to rent a flat rather than buy a property on a mortgage. Also in this article, we learn that young people earn the least among all age groups participating in the survey - between 5 and 25 thousand rubles. It is worth noting that 12,792 rubles is the minimum wage in Russia as of February 1, 2021 (Elagina, 2021). The authors also indicate that over half of the young (58.2\%) try to obtain financial income from various sources. With a high degree of probability, this means that they do not have a stable income. Finally, the authors of the article leave the reader with the question of whether people without a fixed salary, living with their parents and earning below the national minimum, often without an official contract, have the ability to get a mortgage. However, Russian-language foreign websites, such as the website of the International Labour Organization affiliated with the United Nations, are trying to describe the situation of young people during the pandemic, presenting the results of the report on the situation of young people in the world in the time of the epidemiological crisis ( $I z-z a$ pandemii COVID-19.., 2020).

The economic instability associated with the pandemic is also contributing to the current situation. According to a survey of October 2020, almost two-thirds (64\%) of young families where the spouses were between the ages of 18 and 25, declared no money for other goods, apart from food and clothing (Vederyna, 2020). At the same time, the authors of the research write that young married couples, working in the service sector and having no children, are in the worst situation. This problem is related to the lack of social assistance that families with children could count on. Interestingly, the social policy applied in the COVID-19 
era slightly weakened the dynamic increase in the level of poverty among Russian families. Although it increased from $12.3 \%$ at the end of 2019 to $12.6 \%$ and $13.2 \%$ in the first and second quarter of 2020, the growth dynamics was lower than in previous years. Especially in the period from April to June 2020, the dynamics was much lower than in the previous two years. Moreover, the discussed trend shows that the applied social assistance, introduced by the Russian government at the beginning of 2020, mitigates the negative effects of the economic crisis.

One of the key tools used by the Kremlin was to increase the maximum amount of monthly unemployment benefit from 8,000 rubles (around PLN 420 ) to 12,130 rubles (around PLN 630) and a number of the aforementioned benefits for families with children and for retirees (World Bank Report, 2020, p. 36). However, as emphasized by Elena Trubnikova from the research company FinExpertiza, most often young specialists are those who lose their jobs and most of them do not have savings (Trubnikova, 2020). Russian youth cannot count on small private businesses, which are strong in other parts of the world. As the analysts of the Central Bank of Russia argue in their report: "Exiting the Crisis: Why Young Companies Are So Important", even in the period of stabilization, the Russian economy struggled to increase productivity. The potential of young, developing companies was quickly depleted, it lasted no more than a year or two, and among companies already on the market, productivity not only does not increase, but it often drops. The report states that in the period 2009-2015 in $10 \%$ of the most efficient companies, labour productivity increased by $30 \%$, and in $50 \%$ of the least effective companies it decreased by 5 times. The government's reluctance to implement comprehensive solutions to improve the situation may affect the performance of companies both during and after the pandemic, as it is difficult for them to survive now, having problems obtaining financial support and not tightening contacts with suppliers. The authors of the report suggest that during the crisis of 1998, the government acted differently - then the Russian government focused on intensifying private investment, which resulted in an increase in both private sector income and work efficiency (Bazanova, 2020).

As we are also convinced by Maria Konyagina and Maria Krasnopevtseva, the problem is also the lack of innovative economy and insufficient participation of young people in its development. In their text, the researchers prove that despite the premises for business development in Russia, business is not popularized, and young entrepreneurs cannot expect to receive a bank loan due to high interest rates and unfavourable conditions (Konyagina \& Krasnopevtseva, 2019). Sergey Khestanov, associate professor of the Russian Academy of National 
Economy and Public Administration, also recognizes the economic problems that Russian youths face. He believes that "there will only be support from the state (for young people) when there is high social tension, so it is highly probable that the service and entertainment sector, where young people are most often employed, will suffer more than others in this wave of pandemic" (Konyagina \& Krasnopevtseva, 2019). The negative effects of unemployment are also noticed by the Russian researcher Tatiana Chekanova, who points out that "the high level of unemployment among young people leads to the formation of a lifestyle without work, involvement in crime, it may lead to social outbreaks and shocks, and ultimately hinders the development of the working potential of the society" (Chekanova, 2015).

The situation in which Russia's economic condition is assessed as the worst by young people is confirmed by research carried out at the turn of October and November 2020 by the Russian institute "FOMnibus". As many as 55\% of people aged 18-30 assess the current economic situation of their homeland as bad. It is satisfactory for $37 \%$ of the respondents, and good for only $5 \%$ of the respondents (Ekonomicheskaya situatsiya $v$ Rossii...,2020). Thus, researchers, economists and scientists only confirm what we learned from the results of the cited studies. As Mateusz Kamionka argues, it is not the youth radicalism that is the cause of student protests in the former USSR, and moderate-minded youth are the most likely to take to the streets (Kamionka, 2020). Therefore, it will be reasonable to assume that it is the economic reasons of politically unaligned youth that may be the reason for the escalation of the protests, despite the fact that as many as $38 \%$ of Russian youth aged $18-24$ have a positive attitude towards people who participated in the January protests aimed at supporting Navalny. $41 \%$ have a neutral attitude to it, and $22 \%$ have a negative attitude to it (see: Yanvarskiye protesty, 2021). In the same age group, as many as $27 \%$ of respondents replied that they followed the course of the demonstration in detail, and only $14 \%$ had not heard of these events at all (Yanvarskiye protesty, 2021). By using the economic sentiment of the Russians, Navalny is trying to create a conviction that Putin is personally responsible for the economic problems of the Russian state. According to a survey conducted in March 2020,38\% of Russians believe that President Putin represents the interests of: "oligarchs, bankers and big companies", and $37 \%$ of those questioned replied that he represents the interests of: "employees of secret services, the army and the Ministry of the Interior" (Otnosheniye $k$ Vladimiru Putinu, 2020). This is especially evident in the era of the coronavirus pandemic. To confirm the above information, the opinions of Paweł Bielicki can 
be cited, as he argues that the priority for the current government is to support large enterprises and institutions directly related to the Kremlin (Bielicki, 2020, p. 120). Thus, it can be presumed that most Russians agree with the statements propagated in subsequent materials of the Foundation for Fighting Corruption established by Navalny. Regardless of the above views, according to the authors of the commentary of the Center for Eastern Studies "Russia at the Beginning of 2021: Political, Social and Economic Situation", the Russian society is not yet willing to participate more widely in the demonstrations, as it is in a state of "hibernation" and it is focused on social but non-political activity, as well as on the will to survive the pandemic (Domańska et al., 2021). They also notice the increasing popularity of the Internet among the youngest age group, which is important because it is the only "oasis" of freedom of information among the government propaganda surrounding them. In the bulletin of the Polish Institute of International Affairs from July 2020, Jakub Benedyczak and Maciej Zaniewicz argue that: "in the short term, due to the COVID-19 pandemic, there will be a significant increase in unemployment (even up to 10\%) and a decrease in real incomes of Russians (by 6\%), which may result in intensified economic protests. It is doubtful, however, that they would turn into political protests capable of shaking the regime's stability" (Benedyczak \& Zaniewicz, 2020). Today we know that due to the bad economic situation and the case of Navalny, 2021 began with relatively significant protests. Given the lack of a viable Kremlin's political program for young people, it will be difficult to reverse this trend without major systemic changes.

\section{SUMMARY}

Summing up these considerations, we must say that the years 2020-2021 meant the abandonment of illusions among young Russians as to the nature of Vladimir Putin's regime. It has become clear to them that the present Russian authorities will not seek to increase democratic freedoms, limit corruption or increase the chances of decent employment in the labour market, and thus the wealth of citizens. The government's inadequate response to the COVID-19 pandemic, the disclosure by Navalny of the corruption of the President and his entourage, and the suppression of protests after the oppositionist's return to the country and his arrest, may have irreversible and long-term negative consequences for the reputation of the leader of the Russian state among young people. Although the 
Kremlin temporarily took control of the situation with a hastily created narrative that the President did not own the property in question, the trust among young citizens in the head of state has been seriously undermined and it seems to remain undermined for a long time, and its restoration will be a very difficult task for the authorities (Guetta, 2021, p. 44).

Regardless of the above-mentioned complications, the Kremlin will strive to marginalize the role of social media in this age group. An example of such intentions is the slowdown of Twitter speed by Russian Internet surveillance in April 2021 (see: Rosja. Działanie Twittera..., 2021). According to Anastasia Sergeyevna from the Association "For a Free Russia", young people will continue their political activity, but it will depend on whether the harassment by the state (Rosguardia - the National Guard) turns into the use of other means against them, including the use of firearms (see: Kłamstwa Putina nieprzypadkowe..., 2020). However, this scenario is not very realistic at the moment, as Moscow does not want to use all its cards unnecessarily so as not to exacerbate social tensions. It should be assumed that the authorities may increase their efforts to influence the youth through television and websites, such as Sputnik, promoting the Kremlin's political line. However, such a tactic may turn out to be ineffective, because, thanks to alternative sources of mass media, young people are increasingly better versed in Russian reality and are reluctant to obtain information from the mass media associated with the rulers. Undoubtedly, the authorities will also count on the tiredness and discouragement of the young. These words are confirmed by the opinion of D. Volkov, mentioned in the text, who indicates that after suppressing the demonstrations, Navalny's electorate more and more often shows apathy and reluctance to take further action. In his opinion, young people have no idea what to do next (Barysheva, 2021). This allows us to draw the conclusion that despite their slogans about the development of democracy, reducing corruption and improving the economic situation, they do not have a broader idea how to achieve the goals they articulate. The situation is aggravated by the fact that they are still often not interested in politics and declare electoral absenteeism. This is evidenced by the research conducted by Lev Gudkov, which shows that young Russians do not go to elections because they do not believe that the elections are independent. According to the data he collected, only about $25-30 \%$ of those entitled aged 18 to 24 , and about $65-70 \%$ of retirees participate in the elections (Kolesnychenko, 2021). 


\section{ReFERENCES:}

A Hollow Superpower (2016, March 19). Retrieved from: https://www.economist.com/ leaders/2016/03/19/a-hollow-superpower.

Antirossiyskiye sanktsii (2020, March 17). Retrieved from: https://www.levada. ru/2020/03/17/antirossijskie-sanktsii/.

Asmolov, G., \& Kolozaridi, P. (2020). Run Runet Runaway: The Transformation of the Russian Internet as a Cultural-Historical Object. In: D. Gritsenko, M. Wijermars, \& M. Kopotev (Eds.). The Palgrave Handbook of Digital Russia Studies (pp. 277-296). London: Palgrave Macmilian.

Barysheva, E. (2021, March 31). Can Imprisoned Navalny Draw 500,000 Protesters in Russia? Retrieved from: https://www.dw.com/en/can-imprisoned-navalny-draw500000-protesters-in-russia/a-57066502.

Bazanova, E. (2020, September 14). Krizis ubivayet molodyye $i$ bystrorastushchiye rossiyskiye kompanii. Retrieved from: https://www.vtimes.io/2020/09/14/krizisubivaet-kompanii-a122.

Benedyczak, J., \& Zaniewicz, M. (2020, July 29). Gospodarka rosyjska w czasie COVID19. Biuletyn PISM, 159. Retrieved from: https://pism.pl/publikacje/Gospodarka_ rosyjska_w_czasie_COVID19.

Bennetts, M. (2014). Dokopać Kremlowi. Walka nowych rosyjskich dysydentów o odsunięcie Putina od władzy. Warszawa: Wydawnictwo Literackie MUZA S.A.

Bielicki, P. (2020). Polityczno-ekonomiczne implikacje epidemii koronawirusa dla Federacji Rosyjskiej. Studia Polityczne, 48(3), 107-135. DOI: 10.35757/STP.2020.48.3.05.

Bryc, A. (2021, January 23). „Nawalny, my $z$ toba!”. Protesty $w$ Rosji to przełom $i$ test. Retrieved from: https://www.polityka.pl/tygodnikpolityka/ swiat/2100243,1,nawalny-my-z-toba-protesty-w-rosji-to-przelom-i-test.read.

Chekanova, T.E. (2015). The Problem of Youth Unemployment in Russia as a Priority Problem of the Modern Labor Market. M.I.R. [Modernization. Innovation. Research], 6(3), pp. 171-177.

Domańska, M., Menkiszak, M., Rogoża, J., \& Wiśniewska, I. (2021, January 8). Rosja u progu 2021 roku. Sytuacja polityczna, spoteczna i gospodarcza. OSW Commentary, 371. Retrieved from: https://www.osw.waw.pl/sites/default/files/komentarze_371_0. pdf.

Domańska, M., \& Rogoża, J. (2021, January 25). Rosja: masowe protesty w obronie Nawalnego. Retrieved from: https://www.osw.waw.pl/pl/publikacje/analizy/2021-01-25/ rosja-masowe-protesty-w-obronie-nawalnego.

Ekonomicheskaya situatsiya $v$ Rossii: monitoring (2020, November 20). Retrieved from: https://fom.ru/Ekonomika/14499.

Elagina, D. (2021, March 22). Monthly Minimum Wage in Russia and Its Largest Cities as of January 1, 2021. Retrieved from: https://www.statista.com/statistics/1023237/ russihttps://tass.ru/ekonomika/8197209a-monthly-minimum-wage.

Fil'm "Dvorets dlya putina" (2021, February 8). Retrieved from: https://www.levada. $\mathrm{ru} / 2021 / 02 / 08 /$ film-dvorets-dlya-putina/?fbclid=IwAR0u2UMxc1P5-Z2FAJrxb_ mvFnXx0ILPgdRAe9rlDvxt6vFGBdemXVzHWuk. 
Gresh, J., Jones, S.G., \& Loughran, E. (2020). Implications and Takeaways. In: S.G Jones (Ed.). Moscow's War in Syria (pp. 64-71). Washington: Center for Strategic and International Studies.

Gudkov, L., Zorkaya, N., Kochergina, E., Pipiya, K., \& Ryseva, A. (2020). Russia’s “Generation Z": Attitudes and Values 2019/2020. Moscow: Friedrich-Ebert-Stiftung in the Russian Federation. Retrieved from: https:/library.fes.de/pdf-files/bueros/ moskau/16134.pdf.

Guetta, B. (2021). As in Belarus: The Beginning of the End of a Reign in Russia. European View, 20(1), 40-46. DOI: 10.1177/17816858211003718.

Issledovaniye: molodezh'v Rossii okazalas' samoy podgotovlennoy k ekonomicheskomu krizisu (2020, April 9). Retrieved from: https://tass.ru/ekonomika/8197209.

Iz-za pandemii COVID-19 boleye 70 protsentov molodykh lyudey ne mogut normal'no uchit'sya (2020, August 11). Retrieved from: https://www.ilo.org/moscow/news/ WCMS_753125/lang--ru/index.htm.

Kacewicz, M. (2019, March 18). Rosyjski ambasador w Mińsku ma ujarzmić Alaksandra Łukaszenkę. Retrieved from: https://belsat.eu/pl/news/rosyjski-ambasador-wminsku-ma-ujarzmic-alaksandra-lukaszenke/.

Kamionka, M. (2020). Yunyy revolyutsioner? Uroven' radikalizma kak faktor protestnykh nastroyeniy ukrainskoy molodezhi. Vestnik Tomskogo gosudarstvennogo universiteta. Filosofiya. Sotsiologiya. Politologiya, 57, 224-235. DOI: 10.17223/1998863X/57/21. Kłamstwa Putina nieprzypadkowe. Chce $w$ złym świetle przedstawić Polskę przed rozmowami $w$ Waszyngtonie (2020, June 19). Retrieved from: https://www.polskieradio24.pl/5/1223/Artykul/2535088,Klamstwa-Putina-nieprzypadkowe-Chce-wzlym-swietle-przedstawic-Polske-przed-rozmowami-w-Waszyngtonie.

Kolesnikov, A. (2021, January 26). Russian Protest in the Age of Online Transparency. Retrieved from: https://carnegie.ru/commentary/83724.

Kolesnychenko, T. (2021, February 4). Putin odkrył, że w Rosji jest młodzież. I bardzo się zdziwit. Retrieved from: https://magazyn.wp.pl/kobieta/artykul/putin-odkrylze-w-rosji-jest-mlodziez-i-bardzo-sie-zdziwil.

Konyagina, M.N., \& Krasnopevtseva, M. (2019). Molodezh i sotsialnoe predprinimatelstvo v Rossii [Youth and Social Entrepreneurship in Russia]. Rossiyskoe predprinimatelstvo, 20(1), 159-172. DOI: 10.18334/rp.20.1.39769.

Kowal: Nawalny musi dostosować narrację do oczekiwań Rosjan, a nie Zachodu (ROZMOWA) (2021, January 28). Retrieved from: https://biznesalert.pl/rosjanawalny-putin-polityka-kreml-kowal-bezpieczenstwo-polska/.

Kreml' nazval nedopustimymi nesanktsionirovannyye aktsii 23 yanvarya (2021, January 22). Retrieved from: https://www.kommersant.ru/doc/4660351.

Martynov, K. (2021, January 23). Drugaya yedinaya Rossiya. Retrieved from: https:// novayagazeta.ru/articles/2021/01/23/88848-drugaya-edinaya-rossiya.

Meyer-Olimpieva, I. (2019, October 30). Russia's Young Civic Activism: Lessons from the Moscow Protests. Retrieved from: https://www.wilsoncenter.org/blog-post/ russias-young-civic-activism-lessons-the-moscow-protests.

Młodzi Rosjanie problemem dla Putina. „Żyją już w innej rzeczywistości” (2021, March 
23). Retrieved from: https://forsal.pl/swiat/rosja/artykuly/8126403,mlodzi-rosjanieproblemem-dla-putina.html.

Moroz, O. (2020). 'We Will Not Forget, We Will Not Forgive!': Alexei Navalny, Youth Protest and the Art of Curating Digital Activism and Memory in Russia. In: S. Merrill, E. Keightley, \& P. Daphi (Eds.). Social Movements, Cultural Memory and Digital Media. Mobilising Mediated Remembrance (pp. 249-274). London: Palgrave Macmilian.

Not Just Navalny: Economic Woes also Drive Russians to Protest (2021, February 1). Retrieved from: https://www.aljazeera.com/economy/2021/2/1/not-just-navalnyrussians-also-protest-economic-pain.

Novaya aktsiya $v$ podderzhku Naval'nogo. Glavnoye (2021, January 31). Retrieved from: https://www.rbc.ru/politics/31/01/2021/6013f2a99a79474815347780.

“On nie jest dla was Dimka". Ukryte bogactwa Miedwiediewa wydały jego buty z żólta podeszwa (2019, December 29). Retrieved from: https://www.polskieradio24. pl/5/1223/Artykul/2428310,On-nie-jest-dla-was-Dimka-Ukryte-bogactwaMiedwiediewa-wydaly-jego-buty-z-zolta-podeszwa.

Otnosheniye k Vladimiru Putinu (2020, April 14). Retrieved from: https://www.levada. $\mathrm{ru} / 2020 / 04 / 14 /$ otnoshenie-k-vladimiru-putinu-4/.

Pandemiya koronavirusa mozhet boleznenno otrazit'sya na urovne zhizni molodezhi - issledovaniye (2020, September 2). Retrieved from: https://roscongress.org/ news/pandemija-koronavirusa-mozhet-boleznenno-otrazitsja-na-urovne-zhiznimolodezhi-issledovanie/.

Pozychanyuk, V., Khokhlov, O., \& Mironenko, P. (2021, March 5). Fiziki ne shutyat. Kriminalnaya istoriya vladel'sev «Sitilinka». Retrieved from: https://thebell.io/ fiziki-ne-shutyat-kriminalnaya-istoriya-vladeltsev-sitilinka.

Rescheto, J. (2021, February 6). Rosja: przepetnione cele, przypadkowe aresztowania. Retrieved from: https://www.dw.com/pl/rosja-przepe\%C5\%82nione-cele-przypadkowe-aresztowania/a-56477779.

Reyting Putina sredi molodezhi rukhnul na novoye «dno» (2020, December 11). Retrieved from: https://www.finanz.ru/novosti/aktsii/reyting-putina-sredimolodezhi-rukhnul-na-novoe-dno-1029884449.

Rosja. Działanie Twittera będzie spowolnione do 15 maja (2021, April 5). Retrieved from: https://www.pap.pl/aktualnosci/news\%2C846294\%2Crosja-dzialanie-twitterabedzie-spowolnione-do-15-maja.html.

Roth, A. (2021). Tens of Thousands Protest in Russia Calling for Navalny's Release (2021, January 23). Retrieved from: https://www.theguardian.com/world/2021/jan/23/ alexei-navalny-supporters-join-protests-across-russia.

Sasse, G., \& Krawatzek, F. (2020, June 24). Young Russians Want Putin to Step Back From Power. Retrieved from: https://carnegieeurope.eu/2020/06/24/young-russianswant-putin-to-step-back-from-power-pub-82357.

Shurlakova, N., \& Wojtkowiak, M. (2018). Młodzi w social mediach - wybrane aspekty funkcjonowania polskich i rosyjskich studentów w E-sieci. Zabawy i Zabawki: kwartalnik poświęcony zagadnieniom ludyzmu i ludyczności, 16, 163-187. 
Starchenko, A. (2021, February 24). Life under One Leader: Kremlin's Relationship with the Russian Youth. Retrieved from: https://neweasterneurope.eu/2021/02/24/lifeunder-one-leader-kremlins-relationship-with-the-russian-youth/.

Sukhovey, E. (2020, November 11). «Glavnoye - umiet' stushat' i slyshat'»: chto meshayet molodym spetsialistam nayti rabotu mechty. Retrieved from: https://www.forbes. $\mathrm{ru} /$ forbeslife/413469-glavnoe-umet-slushat-i-slyshat-chto-meshaet-molodymspecialistam-nayti-rabotu.

„Tak postępuja terroryści”. Putin komentuje protesty w obronie Nawalnego (2021, January 25). Retrieved from: https://tvn24.pl/swiat/rosja-wladimir-putin-o-protestach-wobronie-aleksieja-nawalnego-4998475.

Troianovski, A., Kramer, A.E., Nechepurenko, I., \& Higgins, A. (2021, January 31). Russia Protesters Defy Vast Police Operation as Signs of Kremlin Anxiety Mount. Retrieved from: https://www.nytimes.com/2021/01/31/world/europe/russia-protests-navalnylive-updates.html.

Trubnikova, E. (2020, October 27). Krizis molodosti: dvum tretyam molodykh semey v pandemiyu deneg khvatilo lish' na yedu i odezhdu. Retrieved from: https://finexpertiza.ru/press-service/researches/2020/krizis-molodosti/.

Trushin, A. (2020, June 1). Bezrabotnyy vozrast. Na rynke truda katastroficheski upal spros na molodykh spetsialistov. Retrieved from: https://www.kommersant.ru/ doc/4341606.

Vederyna, E. (2020, October 28). Glavnoy zhertvoy koronakrizisa stali molodyye sem'i. Retrieved from: https://www.vedomosti.ru/society/articles/2020/10/28/844994zhertvoi-koronakrizisa.

Vlasti Bashkirii prizvali roditeley ne otpuskat' detey na aktsii 23 yanvarya (2021, January 22). Retrieved from: https://ria.ru/20210122/aktsii-1594183837.html.

World Bank Report (2020). Russia Economic Report \#44: Russia's Economy Loses Momentum amidst COVID-19 Resurgence; Awaits Relief from Vaccine. Retrieved from: http://pubdocs.worldbank.org/en/520231608062784328/Russia-EconomicReport-44-in-English.pdf.

Yanvarskiye protesty (2021, February 10). Retrieved from: https://www.levada. ru/2021/02/10/yanvarskie-protesty.

Zapesotsky, A. (2021, February 4). Rossii neobkhodimo predotvratit' molodezhnuyu bezrabotitsu. Retrieved from: https://rg.ru/2021/02/04/rossii-neobhodimo-preodoletmolodezhnuiu-bezraboticu.html.

Zhukov, E. (2021, January 23). Kak vlasti Rossii gotovilis' $k$ aktsiyam v podderzhku Naval'nogo. Retrieved from: https://www.dw.com/ru/kak-vlasti-rf-pytajutsja-nedopustit-akcij-v-podderzhku-navalnogo/a-56306691. 